\title{
CLINICAL FEATURES AND DISEASE COURSE OF CANCER PATIENTS INFECTED WITH SARS-COV-2 DURING ANTICANCER TREATMENTS
}

Aleksandra Babić ${ }^{1}$, Jelena Milin-Lazović ${ }^{2}$, Sanja Milenković ${ }^{3}$, Jelena Dobrić ${ }^{1}$, Zlata Hufnagel ${ }^{1}$, Nenad Miladinović ${ }^{3}$, Sofija Milanović ${ }^{1}$, Marina Stojanović ${ }^{1}$, Sara Filipović ${ }^{1}$, Aleksandar Gavrić ${ }^{1}$ and Nikola Borlja ${ }^{4}$ ${ }^{1}$ Department of Clinical Oncology, Clinical Hospital Center Zemun, Belgrade, Serbia

${ }^{2}$ Institute for medical statistics and informatics, Medical Faculty, Belgrade, Serbia

${ }^{3}$ Department of Clinical Pathology, Clinical Hospital Center Zemun, Belgrade, Serbia ${ }^{4}$ Centogene AG, Rostock, Germany

\author{
KLINIČKE KARAKTERISTIKE I TOK BOLESTI ONKOLOŠKIIH \\ PACIJENATA ZARAŽENIH SARS-COV-2 INFEKCIJOM TOKOM \\ ONKOLOŠKOG LEČENJA \\ Aleksandra Babić1, Jelena Milin-Lazović², Sanja Milenković3 ${ }^{3}$ Jelena Dobrić ${ }^{1}$, Zlata Hufnagel ${ }^{1}$, Nenad Miladinović3, \\ Sofija Milanović1, Marina Stojanović ${ }^{1}$, Sara Filipović ${ }^{1}$, Aleksandar Gavrić ${ }^{1}$ i Nikola Borlja ${ }^{4}$ \\ ${ }^{I}$ Služba kliničke onkologije, Klničko-bolnički centar Zemun, Beograd, Srbija \\ ${ }^{2}$ Institut za medicinsku statistiku i informatiku, Medicinski fakultet, Beograd, Srbija \\ ${ }^{3}$ Služba kliničke patologije, Kliničko-bolnički center Zemun, Beograd, Srbija \\ ${ }^{4}$ Centogene AG, Rostock, Germany
}

\begin{abstract}
Background: Cancer patients infected with SARS-CoV-2 during their active anticancer treatment represent a highly vulnerable population. We aimed this investigation to show clinical features and outcomes of the patients who had mild to moderate COVID-19 symptoms or were asymptomatic at the admission to the COVID Center. Patients and methods: The retrospective study included 25 cancer patients confirmed with SARS-CoV-2 within seven days of their last anticancer treatment. Clinical data were collected from medical records and processed by methods of descriptive and inferential statistics. Results: Patients' mean age was $68.1 \pm 10.4$ years. More than 2/3 of the patients were with ECOG PS 0 and 1 , and about $4 / 5$ of patients were in III or IV cancer stage. The most frequently applied types of therapy were radiotherapy and combined radio/chemotherapy. Eleven (44.0\%) patients had bilateral while $4(16 \%)$ had unilateral pneumonia. The most frequent symptoms were fever (72\%), fatigue (72\%), dyspnea (32\%), and cough (32\%). 1/5 of the patients needed oxy-

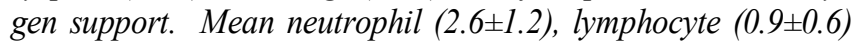
and platelets (200.1 188.1$)$ number significantly increased from admission to discharge ( $p=0.004, p=0.005, p<0.001)$. Median CRP significantly decreased from 40.4 (6.2-96.2) at admission to $11.35(3.75-27.65)$ at discharge $(p=0.008)$. Twenty-four patients were cured, and one patient died. Naso-pharyngeal SARS-CoV-2 clearance time was 19.4 6.9 days; the minimum was seven, and the maximum was 39 days. Conclusion: Cancer patients infected with SARS-CoV-2 during active anticancer treatment can successfully overcome COVID-19 without developing further respiratory or other complications during hospitalization. An increase in lymphocyte and neutrophil counts, with a decrease in CRP, may be markers of a favorable prognosis.
\end{abstract}

Keywords: SARS-CoV-2, COVID-19, cancer, chemotherapy, radiotherapy.

\section{sciendo}

DOI: 10.2478/sjecr-2020-0054

\section{SAŽETAK}

Uvod: Onkološki pacijenti zaraženi SARS-CoV-2 infekcijom tokom aktivnog onkološkog lečenja predstavljaju posebno vulnerabilnu populaciju. Cilj ovog istraživanja je utvrđivanje njihovih kliničkih karakteristika $i$ ishoda lečenja uz uslov da su prilikom prijema u Kovid centar imali blage ili umerene simptome COVID-19 ili su bili bez simptoma. Pacijenti i metode. Ova retrospektivna studija je obuhvatila 25 onkoloških pacijenata kojima je SARS-CoV-2 infekcija potvrdena unutar sedam dana od poslednjeg onkološkog tretmana. Klinički podaci prikupljeni su iz medicinskih baza podataka i obrađeni metodama deckriptivne $i$ inferencijalne statistike. Rezultati: Prosečna starost pacijenata

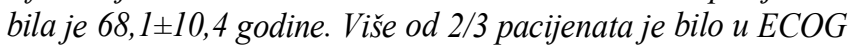
PS 0 i 1, a oko 4/5 pacijenata je bilo u III ili IV stadijumu karcinoma. Najčešće primenjivane vrste onkološkog tretmana su bile radioterapija ili kombinovana radio/hemoterapija. Jedanaest $(44,0 \%)$ pacijenata imalo je obostranu, dok je 4 (16\%) jednostranu pneumoniju. Najčešći simptomi bili su povišena temperatura (72\%), umor (72\%), otežano disanje (32\%) i kašalj $(32 \%)$. 1/5 pacijenata je zahtevala kiseoničnu potporu. Prosečni broj neutrofila na prijemu bio je $(2,6 \pm 1,2)$, limfocita $(0,9 \pm 0,6) i$ trombocita $(200,1 \pm 88,1)$ i statistički je bilo značajno veći na otpustu ( $p=0,004, p=0,005, p<0,001)$. Medijana CRP-a se statistički značajno smanjila sa 40,4 (6,2-96,2) na prijemu $i$ inosila 11.35 (3.75-27.65) na otpustu $(p=0,008)$. Dvadeset četiri pacijenta su izlečena, a jedan pacijent je preminuo. Vreme nazofaringealnog čiśćenja SARS-CoV-2 je iznosilo 19,4士6,9 dana; minimum je bio sedam, a maksimum 39 dana. Zaključak: Onkološki pacijenti zaraženi SARS-CoV-2 infekcijom tokom aktivnog onkološkog lečenja mogu se uspešno oporaviti od COVID-19 bez razvoja dodatnih respiratornih ili drugih komplikacija tokom hospitalizacije. Porast broja limfocita $i$ neutrofila, uz smanjenje CRP mogu biti povoljni prognostički markeri.

Ključne reči: SARS-CoV-2, COVID-19, kancer, hemioterapija, radioterapija.

Corresponding author: Aleksandra Babić Department of Clinical Oncology, Clinical Hospital Center Zemun, Vukova 9, 11080 Zemun, Belgrade, Serbia; tel +381638120622 ville2003@gmail.com 


\section{INTRODUCTION}

In December 2019. China was experiencing an outbreak of a novel beta coronavirus known as severe acute respiratory syndrome coronavirus 2 (SARS-CoV-2) (1). On January 30, 2020, the WHO declared the coronavirus disease 2019 (COVID-19) outbreak a public health emergency of international concern and, in March 2020, began to characterize it as a pandemic (2).

Cancer patients are regarded as a highly vulnerable group in the COVID-19 pandemic due to immunosuppression caused by malignancy and systemic anticancer therapies. The potential to cause harm by SARS-CoV-2 is at least three-fold larger in oncology patients (3). Delivering cancer care during this crisis is challenging, given the competing risks of death from cancer versus death or serious complications from COVID-19 (4).

Cancer patients with "active disease" who are receiving chemotherapy or extensive radiotherapy or who have received chemotherapy in the last three months are at higher risk of infection. The specific risk groups are those with an impaired immune system such as leukocytopenia, low immunoglobulin levels, and long-lasting immunosuppression (steroids, antibodies) (5).

In general, all adults with COVID-19 can be grouped into the several severities of illness categories from asymptomatic infection to critical illness, although the criteria in each category may overlap or vary across guidelines and clinical trials (6). The most common symptoms are fever, cough, sore throat, malaise, fatigue, headache, and muscle pain. The symptoms of lower respiratory tract infectious disease are diagnosed in patients with tracheitis and bronchitis, whereby dyspnea and/or declining oxygen saturation at ambient air often predict bi-lateral ground-glass infiltrates seen earliest on computed tomography (CT) scans, hence identifying viral pneumonia (7).

The first investigations of cancer patients infected with SARS-CoV-2 showed the fatality rate in this population was $5,6 \%$ compared with $2,3 \%$ in the general population (8). Zhang at al. (9) showed that cancer patients develop deteriorating conditions and poor outcomes with high mortality. They also found that within 14 days, anti-tumor therapies were significantly associated with the occurrence of severe clinical events in SARS-CoV-2 infection. On the other hand, Lee at al. analyzed 800 patients with a diagnosis of cancer and symptomatic for COVID-19 and could not identify evidence that cancer patients on cytotoxic chemotherapy or other anticancer treatment were at an increased risk of mortality from COVID-19 compared with those not on active treatment (10).

Due to contradictory and insufficient data related to cancer patients infected with SARS-CoV-2 during the period of their cancer treatment, we aimed this investigation to show our clinical experience related to this vulnerable population and to gather new information on their clinical and laboratory features, and disease course.

\section{METHODS}

\section{Study design and participants}

The retrospective study included 25 cancer patients diagnosed with SARS-CoV-2 infection, referred from the Institute of Oncology and Radiology of Serbia (IORS) to COVID Center Zemun. Patients with different types of solid cancers were tested for SARS-CoV-2 infection on the day of the scheduled continuation of their ongoing anticancer treatment, or during the hospitalization in IORS due to the presence of symptoms or data about risk contacts with persons tested positive for SARS-CoV-2. A confirmed case of SARS-CoV-2 positive patient was defined as a positive result on real-time reverse-transcriptase-polymerase-chain-reaction (RT-PCR) assay of nasal and pharyngeal swab specimens. Only laboratory-confirmed cases were included in the analysis. The patients were admitted to the COVID Center Zemun between March 07, 2020, and April 18, 2020. on the day of the confirmation of SARS-CoV-2 infection. This study included only cancer patients with mild or moderate COVID-19 severity or were asymptomatic at hospital admission. Disease severity was assessed according to the WHO summary of typical features of COVID-19 severity (11). All patients received the last dose of anticancer therapy within seven days before admission to COVID Center Zemun. We obtained data from the medical records for hospitalized patients. Radiologic assessments included chest radiography, and all laboratory testing was performed at hospital admission and further according to the patients' clinical care needs. The patients were discharged from the hospital after they achieved criteria according to Guidance for discharge and ending the isolation in the context of widespread community transmission of SARSCoV-2 of the European Centre for Disease Prevention and Control (ECDC) (12). A COVID-19 patient is considered 'fully discharged' if no symptoms are related to acute COVID-19 for $\geq 48$ hours AND two negative tests at 24-hour intervals from nasal and oropharyngeal swabs.

\section{Statistical analysis}

Descriptive statistics were calculated for the baseline demographic and clinical features. Categorical variables were presented as number and percentage. Continuous data distribution was tested with mathematical and graphical methods. Continuous variables were presented as mean with standard deviation (SD) or median with 25-75 th percentile, according to data distribution. Differences between admission and discharge were analyzed using Student's paired t-test (or Wilcoxon signed rank test) for continuous variables. For all statistical calculations, the significance level $(\alpha)$ was 0.05 . For statistical processing of the obtained results, we used the SPSS software package (version 23.0, SRSS Inc., Chicago, IL). 


\section{RESULTS}

This study included 25 cancer patients with confirmed COVID-19 diagnosis or SARS-CoV-2 infection, mean age $68.1 \pm 10.4$ years. Baseline clinical characteristics are presented in table 1. Male patients were dominant, and the gastrointestinal system was the most affected system, with ECOG PS 0 and 1 in more than $2 / 3$ of the patients. Most of the patients were in III or IV stages of cancer, and radiotherapy or combined radio/chemotherapy were the most frequently applied types of therapy.

In $3 / 4$ of the patients, the main symptoms at the hospital admission were fever and fatigue (table 2). Eleven (44.0\%) patients had bilateral pneumonia (figure 1), while 4 (16) had unilateral pneumonia. At admission, 2/3 of the patients had leucopenia and lymphopenia, without leukocytosis and lymphocytosis in any patient. Neutropenia was present in less than half of the SARS-CoV-2 positive cancer patents. A high level of CRP was present in $2 / 3$ of the patients. Thrombocytopenia was present in $1 / 3$ of the patients and anemia in more than $80 \%$. A high level of D-Dimer was present in all, except for 2 patients with referent values. More than half of the patients had low proteins and albumin levels. The level of LDH was increased in one-third of the patents. Sodium levels were low in 5, while potassium level was low in 6 patients. Low calcium level was present in more than half of the SARSCoV-2 positive patients. The iron level was low in $70 \%$, and ferritin was high in more than half of the patents. Urea and creatinine levels were mostly in reference ranges. Liver enzymes were sporadically increased in some patients (table 3 ).
Mean neutrophils number was $2.6 \pm 1.2$ at admission and significantly increased $3.1 \pm 1.1$ at discharge $\mathrm{p}=0.004$ (figure 2). Mean lymphocytes number also significantly increased from $0.9 \pm 0.6$ to $1 \pm 0.5$ at discharge $(\mathrm{p}=0.005)$, (figure 2 ). NLR and PLR increased at discharge, but change was not significant (NLR 2.83 (1.66-6) to 3.7 (1.81-5.35), $\mathrm{p}=0.346$; PLR 195 (131.17-453.33) to 323.9 (175.75-552.5), $\mathrm{p}=0.607)$. Median CRP significantly decreased from 40.4 (6.2-96.2) at admission to $11.35(3.75-27.65)$ at discharge $(p=0.008)$ (figure 2). Mean number of platelets significantly increased from $200.1 \pm 88.1$ to $300.3 \pm 124.6, \mathrm{p}<0.001$, while mean hemoglobin remained unchanged $(113.4 \pm 19.7$ to $111.4 \pm 17.9$, $\mathrm{p}=0.686$ ).

All patients were treated with hydroxychloroquine. Sixteen $(64.0 \%)$ patients were treated with Azithromycin. The most often applied antibiotics were Azithromycin and Ceftriaxone. In patients with pneumonia, Ceftazidime, Meropenem, Metronidazole, and Levofloxacin were applied depending on the clinical symptoms, CRP values, and performance status of the patients' (table 4). Twenty-four patients were cured, and one patient had a deadly outcome. Negative results of the PCR test were present after $19.4 \pm 6.9$ days; the minimum was seven days and maximal after 39 days.

Table 1. Baseline clinical characteristics of SARS-CoV-2 positive cancer patients with mild to moderate SARS-CoV-2 symptoms at the admission to the Covid center

\begin{tabular}{|c|c|c|}
\hline & & $\mathrm{n}(\%)$ \\
\hline \multirow{2}{*}{ Gender } & male & $18(72)$ \\
\hline & female & $7(28)$ \\
\hline Age* & & $68.1 \pm 10.4$ \\
\hline \multirow{4}{*}{ Localization of the primary tumor } & Gastrointestinal tract (GIT) & $9(36)$ \\
\hline & Urogenital tract (UGT) & $5(20)$ \\
\hline & Respiratory tract (RT) & $6(24)$ \\
\hline & Other & $5(20)$ \\
\hline \multirow{5}{*}{ ECOG PS a } & 0 & $4(16)$ \\
\hline & 1 & $16(64)$ \\
\hline & 2 & $1(4)$ \\
\hline & 3 & $3(12)$ \\
\hline & 4 & $1(4)$ \\
\hline Cancer stage & II & $3(12)$ \\
\hline
\end{tabular}




\begin{tabular}{|l|l|l|}
\hline \multirow{5}{*}{} & IIA & $1(4)$ \\
\cline { 2 - 3 } & III & $9(36)$ \\
\cline { 2 - 3 } & IIIB & $1(4)$ \\
\cline { 2 - 3 } & IV & $6(24)$ \\
\cline { 2 - 3 } & IVA & $5(20)$ \\
\hline \multirow{5}{*}{ Type of current cancer therapies } & HT $^{\text {b }}$ & $2(8)$ \\
\cline { 2 - 3 } & CT $^{\text {c }}$ & $4(16)$ \\
\cline { 2 - 3 } & CT/Biological therapy & $1(4)$ \\
\cline { 2 - 3 } & RT $^{\text {d }}$ & $9(36)$ \\
\cline { 2 - 3 } & HT/RT & $1(4)$ \\
\cline { 2 - 3 } & CT/RT & $5(20)$ \\
\cline { 2 - 3 } & Not started & $3(12)$ \\
\hline Comorbidities & & $16(64)$ \\
\hline Hypertension & & $13(52)$ \\
\hline Diabetes mellitus & & $2(8)$ \\
\hline Unilateral pneumonia & & $11(44)$ \\
\hline Bilateral pneumonia & & \\
\hline
\end{tabular}

*data are expressed as mean \pm sd;
a) ECOG PS - Eastern Cooperative Oncology Group (ECOG) Performance Status
b) HT - hormone therapy;
c) CT- chemotherapy;
d) RT - radiotherapy

Table 2. SARS-CoV-2 symptoms of infected cancer patients on a day of admission to COVID Center

\begin{tabular}{|l|l|l|}
\hline Symptom & Yes & No \\
\hline Fever & $18(72 \%)$ & $7(28 \%)$ \\
\hline Cough & $8(32 \%)$ & $17(68 \%)$ \\
\hline Dyspnea & $8(32 \%)$ & $17(68 \%)$ \\
\hline Need for oxygen support & $5(20 \%)$ & $20(80 \%)$ \\
\hline Fatigue & $18(72 \%)$ & $7(28 \%)$ \\
\hline
\end{tabular}

Table 3. Laboratory findings of SARS-CoV-2 positive cancer patients with mild to moderate SARS-CoV-2 symptoms at the admission to the COVID Center

\begin{tabular}{|l|l|l|}
\hline \multicolumn{1}{|c|}{ Laboratory findings } & \multicolumn{1}{|c|}{ Values } & \multicolumn{1}{c|}{ N (\%) } \\
\hline \multirow{2}{*}{ Leucocytes } & Leucopenia & $18(72)$ \\
\cline { 2 - 3 } & referent values & $7(28)$ \\
\hline \multirow{2}{*}{ Neutrophils } & Neutropenia & $11(44)$ \\
\cline { 2 - 3 } & reference values & $14(56)$ \\
\hline \multirow{2}{*}{ Lymphocytes } & Lymphopenia & $17(68)$ \\
\cline { 2 - 3 } & reference values & $8(32)$ \\
\hline
\end{tabular}




\begin{tabular}{|c|c|c|}
\hline Laboratory findings & Values & N (\%) \\
\hline \multirow[b]{2}{*}{ Platelets } & Thrombocytopenia & $9(36)$ \\
\hline & reference values & $16(64)$ \\
\hline \multirow{2}{*}{ Hemoglobin } & low & $22(88)$ \\
\hline & reference values & $3(12)$ \\
\hline \multirow{2}{*}{ CRP } & reference values & $7(28)$ \\
\hline & high & $18(72)$ \\
\hline \multirow{3}{*}{ D-Dimer } & low & $0(0)$ \\
\hline & reference values & $2(9.1)$ \\
\hline & high & $20(90.9)$ \\
\hline \multirow{3}{*}{ Proteins } & low & $15(60)$ \\
\hline & reference values & $10(40)$ \\
\hline & high & $0(0)$ \\
\hline \multirow{3}{*}{ Albumins } & low & $16(64)$ \\
\hline & reference values & $9(36)$ \\
\hline & high & $0(0)$ \\
\hline \multirow{3}{*}{ LDH } & low & $0(0)$ \\
\hline & reference values & $16(66.7)$ \\
\hline & high & $8(33.3)$ \\
\hline \multirow{3}{*}{ Sodium } & low & $5(20.8)$ \\
\hline & reference values & $19(79.2)$ \\
\hline & high & $0(0)$ \\
\hline \multirow{3}{*}{ Calcium } & low & $14(60.9)$ \\
\hline & reference values & $9(39.1)$ \\
\hline & high & $0(0)$ \\
\hline \multirow{3}{*}{ Potassium } & low & $6(25)$ \\
\hline & reference values & $13(54.2)$ \\
\hline & high & $5(20.8)$ \\
\hline \multirow{3}{*}{ Iron } & low & $14(70)$ \\
\hline & reference values & $6(30)$ \\
\hline & high & $0(0)$ \\
\hline \multirow{3}{*}{ Ferritin } & low & $1(4.8)$ \\
\hline & reference values & $9(42.9)$ \\
\hline & high & $11(52.4)$ \\
\hline \multirow{3}{*}{ Urea } & low & $0(0)$ \\
\hline & reference values & $21(84)$ \\
\hline & high & $4(16)$ \\
\hline \multirow{3}{*}{ Creatinine } & low & $0(0)$ \\
\hline & reference values & $23(92)$ \\
\hline & high & $2(8)$ \\
\hline \multirow{3}{*}{ AST } & low & $0(0)$ \\
\hline & reference values & $15(68.2)$ \\
\hline & high & $7(31.8)$ \\
\hline
\end{tabular}




\begin{tabular}{|l|l|l|}
\hline \multicolumn{1}{|c|}{ Laboratory findings } & \multicolumn{1}{|c|}{ Values } & \multicolumn{1}{c|}{ N (\%) } \\
\hline \multirow{3}{*}{ ALT } & low & $0(0)$ \\
\cline { 2 - 3 } & reference values & $20(90.9)$ \\
\cline { 2 - 3 } & high & $2(9.1)$ \\
\hline \multirow{3}{*}{ GGT } & low & $0(0)$ \\
\cline { 2 - 3 } & reference values & $15(75)$ \\
\cline { 2 - 3 } & high & $5(25)$ \\
\hline
\end{tabular}

Table 3. Laboratory findings of SARS-CoV-2 positive cancer patients with mild to moderate SARS-CoV-2 symptoms at the admission to the COVID Center

\begin{tabular}{|c|c|c|}
\hline Laboratory findings & Values & N (\%) \\
\hline \multirow[b]{2}{*}{ Leucocytes } & Leucopenia & $18(72)$ \\
\hline & referent values & $7(28)$ \\
\hline \multirow[b]{2}{*}{ Neutrophils } & Neutropenia & $11(44)$ \\
\hline & reference values & $14(56)$ \\
\hline \multirow[b]{2}{*}{ Lymphocytes } & Lymphopenia & $17(68)$ \\
\hline & reference values & $8(32)$ \\
\hline \multirow[b]{2}{*}{ Platelets } & Thrombocytopenia & $9(36)$ \\
\hline & reference values & $16(64)$ \\
\hline \multirow{2}{*}{ Hemoglobin } & low & $22(88)$ \\
\hline & reference values & $3(12)$ \\
\hline \multirow{2}{*}{ CRP } & reference values & $7(28)$ \\
\hline & high & $18(72)$ \\
\hline \multirow{3}{*}{ D-Dimer } & low & $0(0)$ \\
\hline & reference values & $2(9.1)$ \\
\hline & high & $20(90.9)$ \\
\hline \multirow{3}{*}{ Proteins } & low & $15(60)$ \\
\hline & reference values & $10(40)$ \\
\hline & high & $0(0)$ \\
\hline \multirow{3}{*}{ Albumins } & low & $16(64)$ \\
\hline & reference values & $9(36)$ \\
\hline & high & $0(0)$ \\
\hline \multirow{3}{*}{ LDH } & low & $0(0)$ \\
\hline & reference values & $16(66.7)$ \\
\hline & high & $8(33.3)$ \\
\hline \multirow{3}{*}{ Sodium } & low & $5(20.8)$ \\
\hline & reference values & $19(79.2)$ \\
\hline & high & $0(0)$ \\
\hline \multirow{3}{*}{ Calcium } & low & $14(60.9)$ \\
\hline & reference values & $9(39.1)$ \\
\hline & high & $0(0)$ \\
\hline
\end{tabular}




\begin{tabular}{|c|c|c|}
\hline Laboratory findings & Values & $\mathbf{N}(\%)$ \\
\hline \multirow{3}{*}{ Potassium } & low & $6(25)$ \\
\hline & reference values & $13(54.2)$ \\
\hline & high & $5(20.8)$ \\
\hline \multirow{3}{*}{ Iron } & low & $14(70)$ \\
\hline & reference values & $6(30)$ \\
\hline & high & $0(0)$ \\
\hline \multirow{3}{*}{ Ferritin } & low & $1(4.8)$ \\
\hline & reference values & $9(42.9)$ \\
\hline & high & $11(52.4)$ \\
\hline \multirow{3}{*}{ Urea } & low & $0(0)$ \\
\hline & reference values & $21(84)$ \\
\hline & high & $4(16)$ \\
\hline \multirow{3}{*}{ Creatinine } & low & $0(0)$ \\
\hline & reference values & $23(92)$ \\
\hline & high & $2(8)$ \\
\hline \multirow{3}{*}{ AST } & low & $0(0)$ \\
\hline & reference values & $15(68.2)$ \\
\hline & high & $7(31.8)$ \\
\hline \multirow{3}{*}{ ALT } & low & $0(0)$ \\
\hline & reference values & $20(90.9)$ \\
\hline & high & $2(9.1)$ \\
\hline \multirow{3}{*}{ GGT } & low & $0(0)$ \\
\hline & reference values & $15(75)$ \\
\hline & high & $5(25)$ \\
\hline
\end{tabular}

Table 4. The list of applied therapy and the outcome of SARS-CoV-2 positive cancer patients with mild to moderate SARS-CoV-2 symptoms at the admission to the Covid center

\begin{tabular}{|l|l|l|}
\hline \multicolumn{1}{|c|}{ Type of therapy } & \multicolumn{1}{|c|}{ Aplication of therapy } & \multicolumn{1}{c|}{ (\%) } \\
\hline \multirow{2}{*}{ Hydroxychloroquine } & No & $0(0)$ \\
\cline { 2 - 3 } & Yes & $25(100)$ \\
\hline \multirow{2}{*}{ Azithromycin } & No & $9(36)$ \\
\cline { 2 - 3 } & Yes & $16(64)$ \\
\hline \multirow{2}{*}{ Ceftriaxone } & No & $12(48)$ \\
\cline { 2 - 3 } & Yes & $13(52)$ \\
\hline \multirow{2}{*}{ Ceftazidime } & No & $24(96)$ \\
\cline { 2 - 3 } & Yes & $1(4)$ \\
\hline \multirow{2}{*}{ Meropenem } & No & $1(4)$ \\
\cline { 2 - 3 } & Yes & $22(88)$ \\
\hline \multirow{2}{*}{ Metronidazole } & No & $3(12)$ \\
\cline { 2 - 3 } & Yes & \\
\hline
\end{tabular}




\begin{tabular}{|l|l|l|}
\hline \multicolumn{1}{|c|}{ Type of therapy } & \multicolumn{1}{|c|}{ Aplication of therapy } & \multicolumn{1}{c|}{ n (\%) } \\
\hline \multirow{2}{*}{ Levofloxacin } & No & $24(96)$ \\
\cline { 2 - 3 } & Yes & $1(4)$ \\
\hline \multirow{2}{*}{ Outcome } & Death & $1(4)$ \\
\cline { 2 - 3 } & Cured & $24(96)$ \\
\hline
\end{tabular}

Figure 1. Changes of neutrophil, lymphocyte, and CRP counts from admission to discharge of SARS-CoV-2 positive cancer patients with mild

to moderate SARS-CoV-2 symptoms: significantly increase of mean neutrophils and lymphocytes number and decrease of median CRP value at discharge
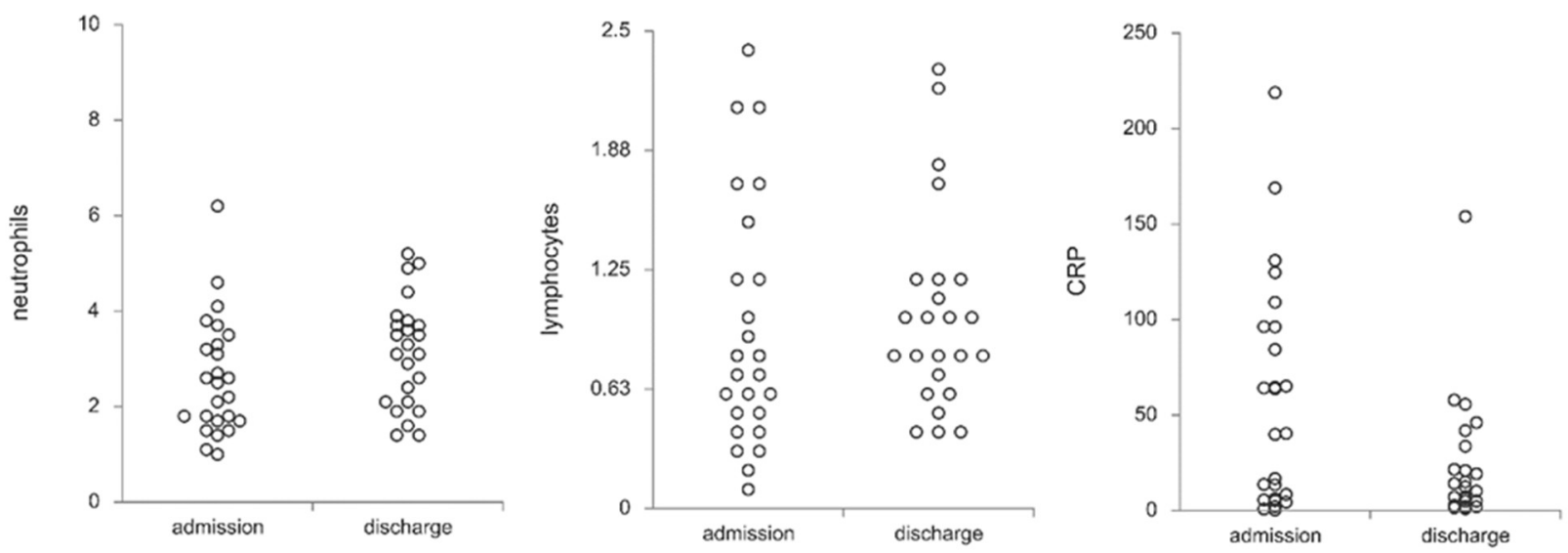

Figure 2. Chest X-ray findings in cancer patients infected with COVID-19 during the cancer treatment: four examples of bilateral pneumonia show patchy or diffuse ground-glass opacity with small fields of consolidation and reticular areas of increased opacity. Patients had no diagnosed lung metastases.

A)

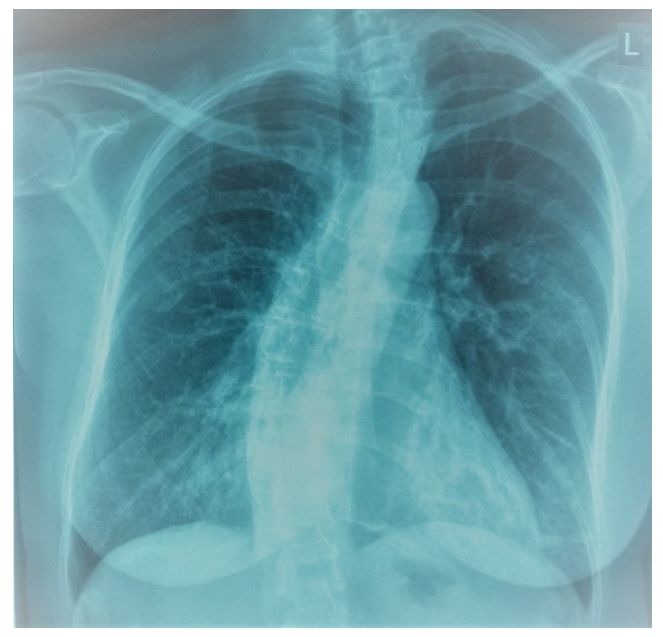

B)

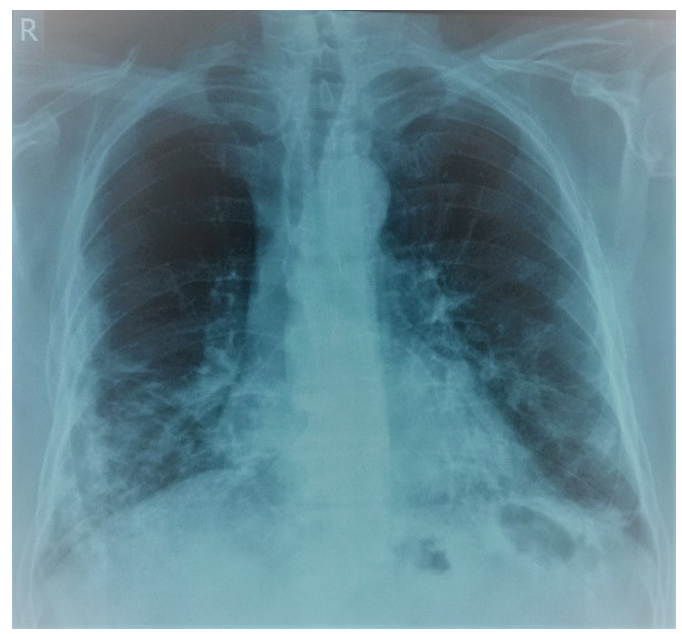


C)

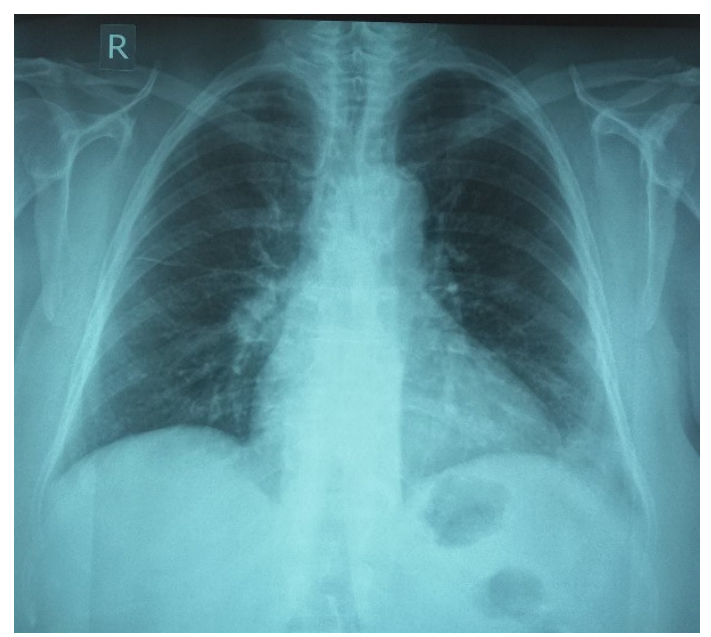

D)

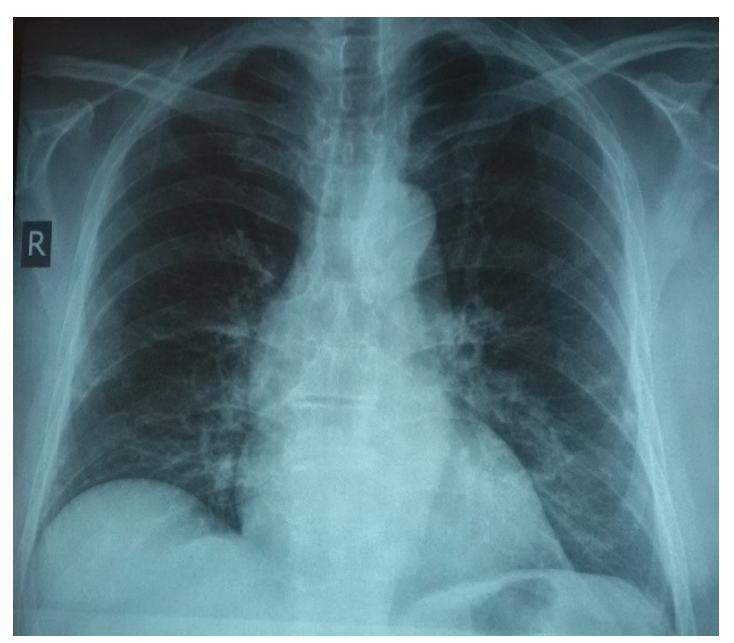

\section{DISCUSSION}

We present the clinical course and laboratory characteristics of 25 cancer patients infected with SARS-CoV-2 during their active anticancer treatment. At presentation, all patients had mild or moderate symptoms or were asymptomatic, and most of them successfully overcame SARS-CoV-2 infection and were discharged from the hospital able to continue their further oncology treatment.

The most common symptoms were typical for COVID19 patients and most frequently included fever, fatigue, cough, and dyspnea. Oxygen support was needed by $1 / 5$ of the patients. The most frequent initial laboratory findings were leukopenia, lymphopenia, neutropenia, and thrombocytopenia. Wang at al. (13) shown that COVID-19 patients had significantly lower total number of lymphocytes and NK cells. They also documented that in responsive patients, total lymphocytes, CD8+ T cells, and B cells increased significantly after treatment, and no significant change was detected in $\mathrm{CD} 4+\mathrm{T}$ cells, $\mathrm{CD} 4+/ \mathrm{CD} 8+$ ratio. In nonresponsive patients, no significant change was detected. Our study showed that the levels of lymphocytes, neutrophils, and thrombocytes significantly increased at discharge, which could have a positive effect on the outcome of the disease.

At the hospital admission, about $2 / 5$ of patients had bilateral and less than $1 / 5$ unilateral pneumonia. The diagnosis of pneumonia was established by clinical and laboratory examination and confirmed by chest X-ray (CXR) of the lungs. The fact was that some incipient pneumonia might have been remained unrecognized because CXR is insensitive in the detection of early disease (14), but, on the other hand, it was useful for establishing a baseline and as follow-up imaging for disease progression (15). Compared to chest CT, CXR appears to have lower sensitivity and might have higher specificity (16).
Anemia was present in $4 / 5$ of patients, and $1 / 5$ of them needed a blood transfusion, mean hemoglobin remained unchanged. The levels of CRP significantly decreased at discharge. The other laboratory findings showed high D-Dimer, hypoproteinemia, and hypoalbuminemia and were in line with the experiences of other authors (9).

Most of our cancer patients infected with SARS-CoV-2 continued to be respiratory stable during the hospitalization and successfully defeated infection. Our experience was completely different from Zhang et al. (9) reported that 53\% of the 28 cancer patients developed severe events, $21,4 \%$ were admitted to intensive care units (ICU), 35,7\% had lifethreatening complications, and $28,6 \%$ of the patients died. Yang et al. (17) also showed that receiving chemotherapy within 4 weeks before symptom onset and male sex were risk factors for death during admission to hospital. According to our research, one patient developed a severe respiratory event and was admitted to the intensive care unit (ICU) for noninvasive mechanical ventilation, and one patient died in the terminal stage of metastatic colorectal cancer with mild respiratory symptoms. Of course, the fact that $80 \%$ of the patients were in good performance status (ECOG 0 or 1 ) could positively contribute to this outcome. Also, large COVID-19 cancer cohorts of predominantly solid organ tumors have shown no significant excess mortality risk from recent chemotherapy $(18,19)$.

Despite the large use of antiviral and/or anti-inflammatory drugs, until now, no proven treatment is available for the current COVID-19 pandemic $(18,20)$. Our patients were treated with hydroxychloroquine and one or more antibiotics, depending on the severity of their symptoms and the presence of pneumonia. They also received multivitamin therapy, adequate rehydration, and all needed symptomatic and supportive therapy. No antiviral agents were used. It remains unclear 
whether the use of any applied treatment was crucial for the clinical course of the disease and the patients' recovery.

The patients could be discharged from the hospital after two consecutively negative test results plus the absence of respiratory symptoms for at least two consecutive days before testing after prescribed therapy was finished. The therapy was prescribed on the day of confirmation of SARSCoV-2 infection. Two consecutive negative RT-PCR results were presented after 7 to 39 days $(19.4 \pm 6.9)$ after the confirmation of infection. Most patients (76\%) took more than 14 days to meet the discharge criteria. Xu at al. (21) observed that time to nasopharyngeal SARS-CoV-2 RNA clearance in their oncology patients was substantially longer than the approximately 17-20 days previously reported in the general population. In their retrospective cohort study, the median time to SARS-CoV-2 clearance was 50 days using the ASCO/CDC criteria of 2 negative RT-PCR assays $>24$ hours apart, and the virus clearance times differed substantially depending on criteria.

The study's limitation is reflected in patients' small sample size and heterogeneity of cancer types. The study is retrospective and non-randomized, which could not have been avoided given the patients' admission circumstances to our center. However, the study's value is reflected in the fact that clinical features and disease courses were monitored in patients infected with SARS-CoV-2 during their active anticancer treatment when their vulnerability to infections is greatest due to the possible toxicity of oncology therapies.

\section{CONCLUSION}

Cancer patients with mild or moderate COVID-19 symptoms or asymptomatic for SARS-CoV-2 infection at presentation can successfully overcome disease without developing any further respiratory or other complications even though the infection occurred during their active anticancer treatment. An increase in neutrophil and lymphocyte counts and a decrease in CRP may be markers of a favorable prognosis.

\section{REFERENCES}

1. Chen N, Zhou M, Dong X, et al. Epidemiological and clinical characteristics of 99 cases of 2019 novel coronavirus pneumonia in Wuhan, China: a descriptive study. Lancet. 2020;395(10223):507-513.

2. World Health Organization. WHO Director General's opening remarks at the media briefing on COVID-19. 2020. Available at: www.who.int/dg/speeches/detail/who-director-general-s-opening-remarks-at-the-media-briefing-on-covid-19. Accessed Jun 20, 2020.

3. El-Shakankery KH, Kefas J, Crusz SM. Caring for our cancer patients in the wake of COVID-19. Br J Cancer. 2020;123(1):3-4.

4. Lewis MA. Between Scylla and Charybdis - Oncologic Decision Making in the Time of Covid-19. N Engl J Med. 2020;382(24):2285-2287.
5. European Society for Medical Oncology. Cancer patient management during the COVID-19 pandemic. Available at: www.esmo.org/guidelines/cancer-patient-management-during-the-covid-19-pandemic. Accessed August 2, 2020.

6. National Institutes of Helth. COVID-19 Treatment Guidelines. Management of Persons with COVID-19. Available at: www.covid19treatmentguidelines.nih.gov/overview/management-of-covid-19. Accessed August 2, 2020.

7. Von Lilienfeld-Toal M, Vehreschild JJ, Cornely O, et al. Frequently asked questions regarding SARS-CoV-2 in cancer patients-recommendations for clinicians caring for patients with malignant diseases. Leukemia. 2020;34(6):1487-1494.

8. Wu Z, McGoogan JM. Characteristics of and Important Lessons From the Coronavirus Disease 2019 (COVID19) Outbreak in China: Summary of a Report of 72314 Cases From the Chinese Center for Disease Control and Prevention [published online ahead of print, $2020 \mathrm{Feb}$ 24]. JAMA. 2020;10.1001/jama.2020.2648.

9. Zhang L, Zhu F, Xie L, et al. Clinical characteristics of COVID-19-infected cancer patients: a retrospective case study in three hospitals within Wuhan, China. Ann Oncol. 2020;31(7):894-901.

10. Lee LYW, Cazier JB, Starkey T, et al. COVID-19 mortality in patients with cancer on chemotherapy or other anticancer treatments: a prospective cohort study. Lancet. 2020;395(10241):1919-1926.

11. World Health Organization. Clinical management of COVID-19. Interim guidance, 27 May 2020. Available at: www.who.int/publications/i/item/clinical-management-of-covid-19. Accessed August 30, 2020.

12. European Centre for Disease Prevention and Control. Guidance for discharge and ending isolation in the context of widespread community transmission of COVID19 - first update. Available at: www.ecdc.europa.eu/sites/default/files/documents/covid-19-guidance-discharge-and-ending-isolation-first $\% 20$ update.pdf. Accessed August 28, 2020.

13. Wang F, Nie J, Wang H, et al. Characteristics of Peripheral Lymphocyte Subset Alteration in COVID-19 Pneumonia. J Infect Dis. 2020;221(11):1762-1769.

14. Czawlytko C, Hossain R, White CS. COVID-19 Diagnostic Imaging Recommendations. Appl Radiol. 2020;49(3):10-15

15. World Health Organization. Use of chest imaging in COVID-19. A rapid advice guide, 11. June 2020. Available at: www.who.int/publications/i/item/use-of-chestimaging-in-covid-19. Accessed August 28, 2020.

16. Cozzi D, Albanesi M, Cavigli E, et al. Chest X-ray in new Coronavirus Disease 2019 (COVID-19) infection: findings and correlation with clinical outcome. Radiol Med. 2020;125(8):730-737.

17. Yang K, Sheng Y, Huang C, et al. Clinical characteristics, outcomes, and risk factors for mortality in patients with cancer and COVID-19 in Hubei, China: a multicentre, retrospective, cohort study. Lancet Oncol. 2020;21(7):904-913. 
18. Esposito S, Noviello S, Pagliano P. Update on treatment of COVID-19: ongoing studies between promising and disappointing results. Infez Med. 2020;28(2):198-211.

19. Lee LYW, Cazier JB, Starkey T, et al. COVID-19 prevalence and mortality in patients with cancer and the effect of primary tumour subtype and patient demographics: a prospective cohort study [published online ahead of print, 2020 Aug 24]. Lancet Oncol. 2020;S1470-2045(20)30442-3.
20. Vijayvargiya P, Esquer Garrigos Z, Castillo Almeida NE, Gurram PR, Stevens RW, Razonable RR. Treatment Considerations for COVID-19: A Critical Review of the Evidence (or Lack Thereof). Mayo Clin Proc. 2020;95(7):1454-1466.

21. Xu W, Piper-Vallillo AJ, Bindal P, et al. Time to SARSCoV-2 Clearance Among Patients with Cancer and COVID-19. Preprint. medRxiv. 2020;2020.07.23.20161000. 